Génét. Sél. Evol., 1986, 18 (2), 123-130

\title{
A new reciprocal translocation in a hypoprolific boar ${ }^{(1)}$
}

\author{
C.P. POPESCU and Jeannine BOSCHER \\ I.N.R.A., Laboratoire de Cytogénétique \\ Centre National de Recherches Zootechniques, $F 78350$ Jouy-en-Josas \\ with technical assistance of Geneviève LE HENAFF and $H$. JOUET \\ I.N.R.A., Station de Génétique quantitative et appliquée \\ C.N.R.Z., F 78350 Jouy-en-Josas
}

\begin{abstract}
Summary
In France, boars are classified by the National Program for Sow Herd Management, according to the size of the litters produced. All boars with an average of less than 8 live-born piglets, from at least 6 litters, are cytogenetically examined. Since 1979, three different reciprocal translocations have been identified by our laboratory in the hypoprolific group. A new fourth reciprocal translocation, not hitherto described, has just been found. The carrier Landrace boar had produced an average $7.2 \pm 2.65$ piglets in 24 litters, i.e. a 31.23 p. 100 reduction of prolificacy. This animal is carrying a new reciprocal translocation involving the small acrocentrics, nb. 16 and 17. The animal production and economic consequences of the chromosomal abnormalities are discussed.
\end{abstract}

Key words : Pig, hypoprolific, reciprocal translocation.

\section{Résumé \\ Une nouvelle translocation réciproque chez un verrat hypoprolifique}

En France, les verrats sont classés par le Programme National de Gestion Technique selon la taille des portées qu'ils produisent. Tous les verrats produisant en moyenne 8 porcelets par portée ou moins, sur un minimum de 6 portées, sont étudiés du point de vue cytogénétique. Ainsi, depuis 1979, trois translocations réciproques différentes ont été identifiées. Une nouvelle translocation, impliquant les chromosomes 16 et 17 est décrite chez un verrat Landrace qui produit $7,2 \pm 2,65$ porcelets en moyenne sur 24 portées. La réduction de la prolificité de cet animal est de $31,23 \mathrm{p}$. 100. Les conséquences des anomalies chromosomiques pour l'élevage sont discutées.

Mots clés : Porc, hypoprolifique, translocation réciproque.

(1) Presented at the 4th American Symposium on Cytogenetics of Domestic Animals. June 9-12, 1985. University of Illinois, Urbana, U.S.A. 


\section{Introduction}

Chromosomal structural abnormalities in man and animals may cause reproductive disorders. The most frequent chromosomal abnormalities connected with reproductive failures in pigs are reciprocal translocations (FechHeIMer, 1981 ; Popescu, $1982 \mathrm{~b}$ ). The consequences of heterozygosity for a reciprocal translocation are the formation of chromosomally unbalanced gametes by nondisjunction. Fertilization with unbalanced gametes results in embryos with unbalanced karyotypes, which are very often lethal. Thus, formation of chromosomally unbalanced embryos due to a reciprocal translocation will lead to reduced litter size.

\section{I. Material and methods}

In France, boars are classified according to litter size, within the National Program for Sow Herd Management. Almost 800.000 animals are checked each year. In cases where the boars are still alive when the listing is published every 3 months, all animals with an average of less than 8 live-born piglets from at least 6 litters are cytogenetically evaluated.

The last hypoprolific case was a Landrace boar which had produced an average $7.2 \pm 2.65$ piglets in 24 litters, i.e. a 31.23 p. 100 reduction of prolificacy (fig. 1). The cytogenetic study was made by classical staining as well as $R, G$ and $T$ - banding methods. The chromosomes were aligned according to the recommendations of the Reading Conference (Ford et al., 1980).

\section{Results and discussion}

This animal was carrying a new reciprocal translocation, not hitherto described, involving chromosomes 16 and 17 (fig. 2). A very small distal segment of chromosome $\mathrm{n}^{\circ} 17$ was translocated to chromosome $\mathrm{n}^{\circ} 16$. Because of the small size of these chromosomes it was not possible to provide evidence for the reciprocal exchange.

Since 1979, three different reciprocal translocations have been identified in the hypoprolific group by our laboratory : 4/14 (Popescu \& Legault, 1979), 3/7 (Popescu et al., 1983) and 5/14 (Popescu et al., 1984). The 16/17 translocation is the fourth onc. For investigation of the consequences of these abnormalities on prolificacy, we produced some animals carrying both $4 / 14$ and $3 / 7$ translocation (BAHRI et al., 1984).

Contrary to cattle, where the most frequent structural abnormality is Robertsonian translocation (Popescu, $1982 \mathrm{a}$ ), reciprocal translocations seem to be the 
most common ones in pigs. Including the latest abnormality described in France, the total number of different reciprocal translocations is now 19 (tabl. 1). The decrease in prolificacy varies between 26 and 100 p. 100 . This variation might be explained by the different behaviour of each abnormal chromosome.

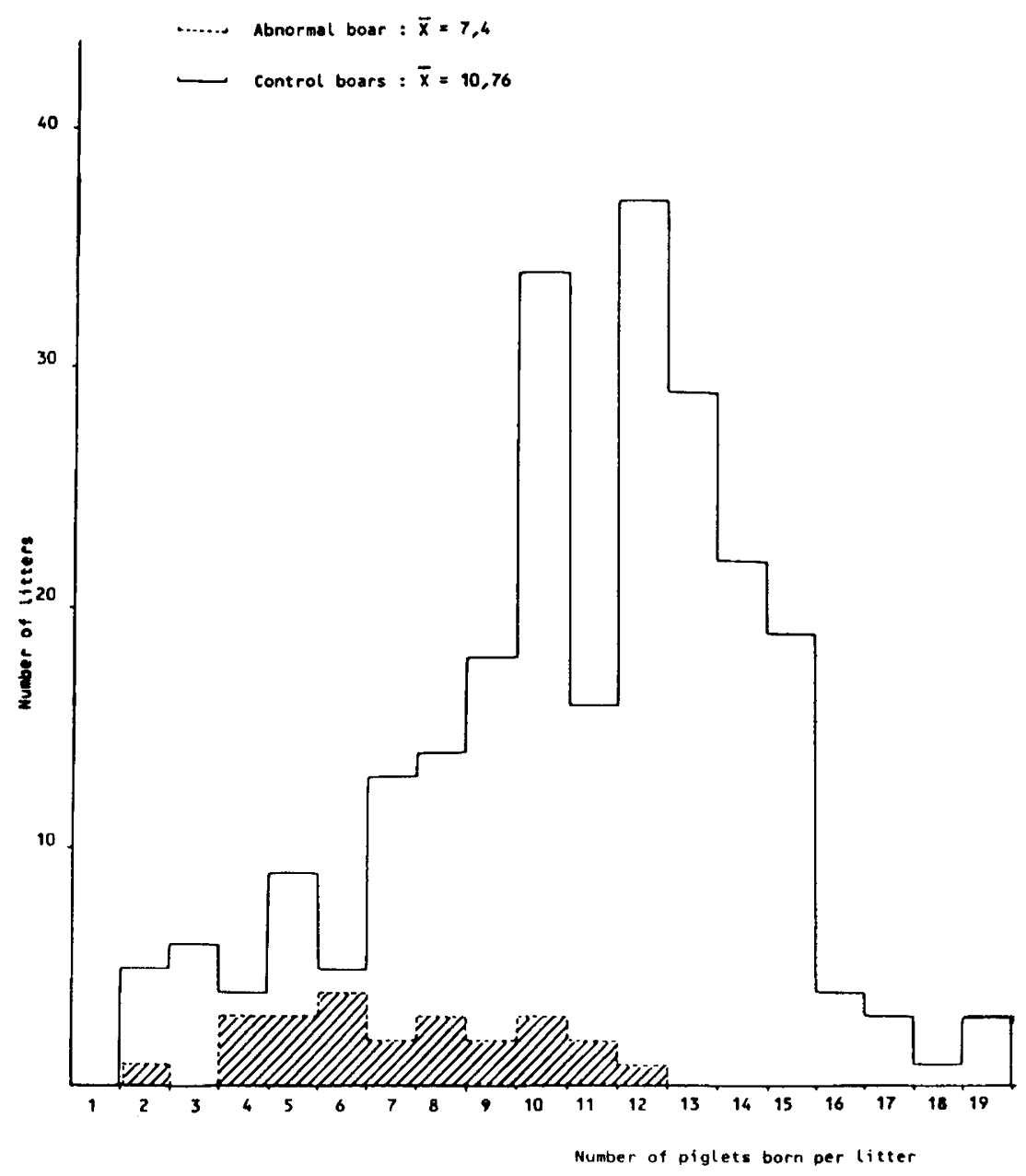

FIG. 1

Histogram of the litters sired by the boar carrying the 16/17 translocation (hatched) and by control boars from the same farm (full line).

Control boars : $\dddot{X}=10,76$.

Abnormal boar : $\overline{\mathrm{X}}=7,4$. 


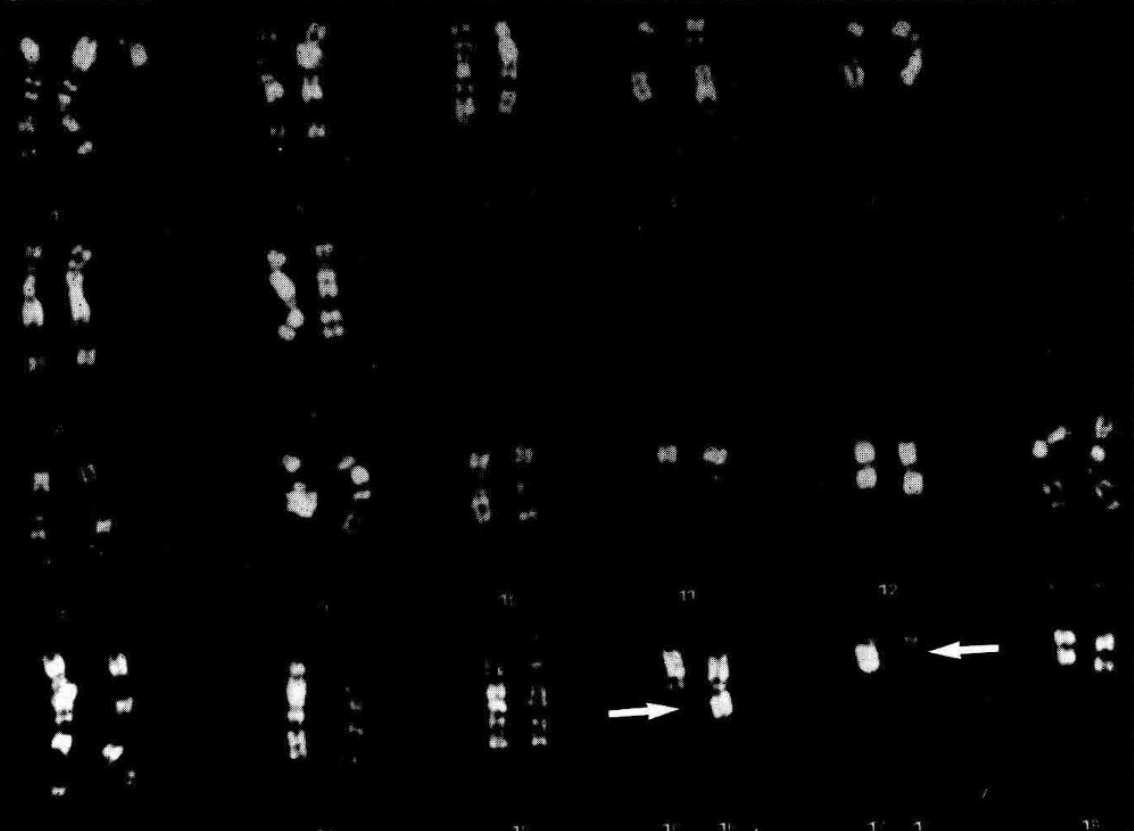

FIg. 2 a

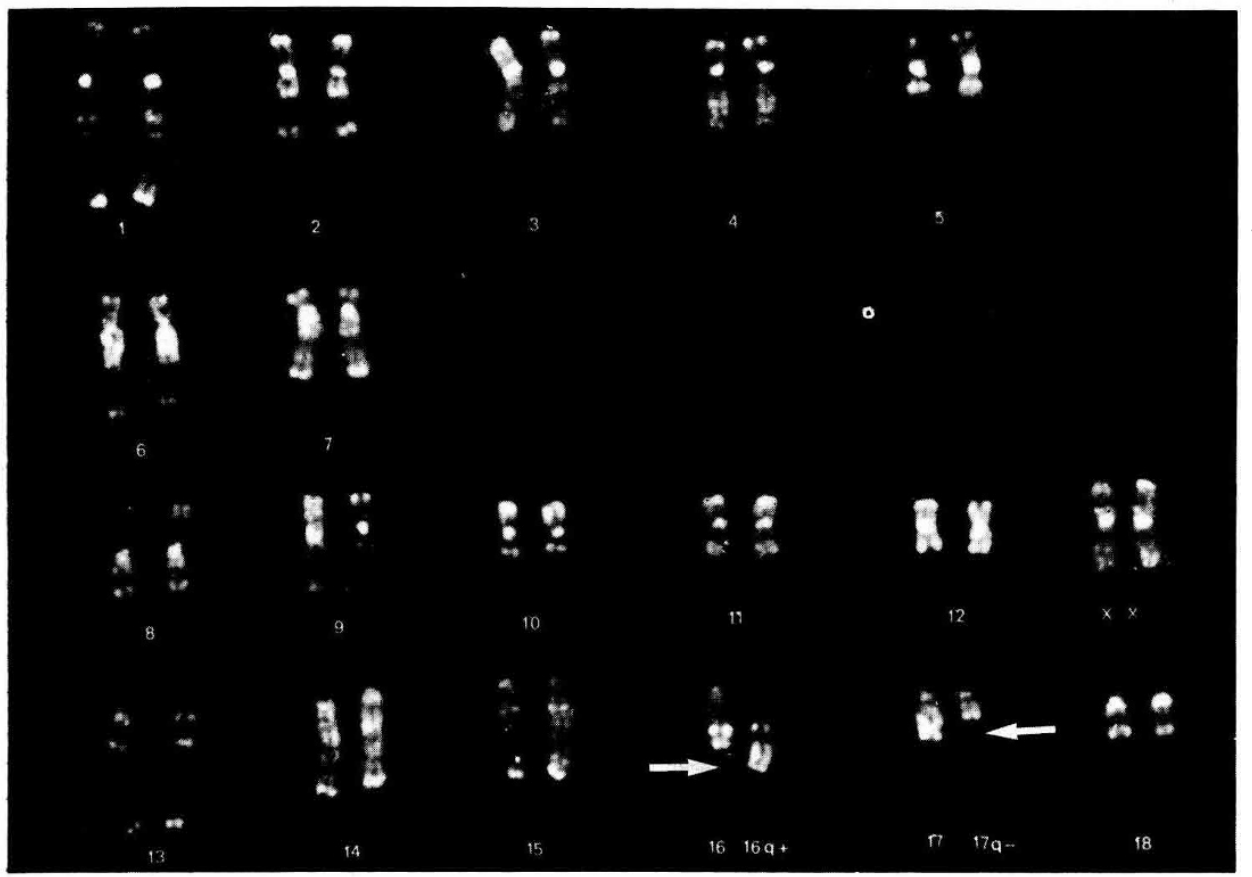

FIG. 2 b 


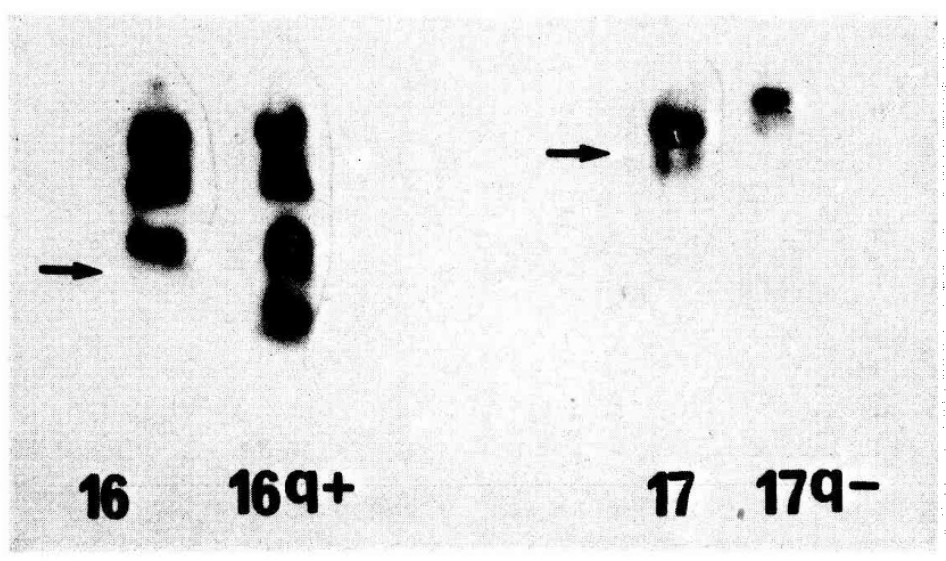

FIG. $2 \mathrm{c}$

$R$-banded (a) and T-banded (b) karyotypes carrying the 16/17 translocation. The G-banded (c) chromosomes no. 16 and 17 carrying the 16/17 translocation.

The frequency and different types of unbalanced gametes produced by each abnormal chromosome depend on the chromosome involved, the size of the translocated segment, and on the presence of chiasmata within the translocated segment. In 3 different cases of reciprocal translocations in pig, cytogenetic studies of embryos before and after implantation showed that reduction of litter size was due to formation of embryos with unbalanced karyotypes. Thus, Ákesson \& Henricson (1972) found 5 different types of unbalanced karyotypes in pre-implantation embryos sired by a boar carrier of $11 / 15$ translocation, KING et al. (1981), seven different types from a boar with a 13/14 translocation and POPESCU \& BOSCHER (1982) six different types from a boar with a $4 / 14$ translocation.

It should be pointed out that in these 3 studies the authors never found an unbalanced karyotype in newborn piglets sired by a heterozygous parent. This shows the lethal character of chromosomal unbalance and accounts for the embryonic mortality rise in carrier animals.

Use of a boar heterozygous for a reciprocal translocation in a natural mating herd may lead to a loss of a 100 piglets even before the farmer has discovered the low prolificacy of the animal. However, it seems that the translocation is maintained in a population over several generations, especially through the females. Indeed, because of the very low repeatability of litter size, it is difficult to detect the abnormality in females and the latter are generally culled after having produced 3-5 litters. The abnormality can therefore easily be maintained in the population (Legault \& Popescu, 1981). For example, the $3 / 7$ translocation, identified for the first time in 1980, is still present in several farms, in 1985 (Popescu, not published). 


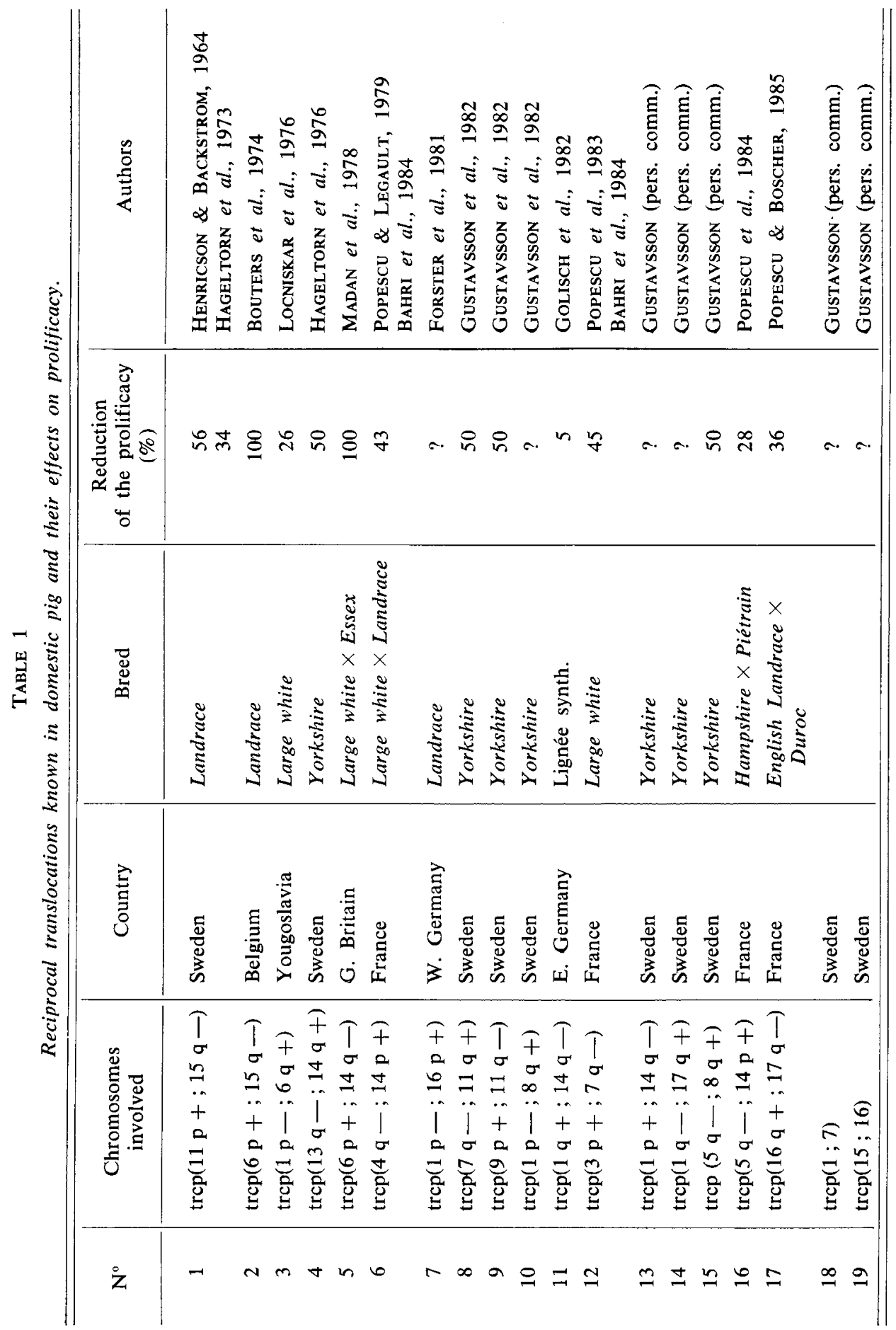


On a sample of 6467 boars who had sired a minimum 6 litters, 10 of them were detected as hypoprolific (i.e. 1.5 p. 1000). Unfortunately cytogenetic examination is possible only on a small proportion of these suspected animals, primarily because they are dead at time of collection. Indeed, since 1979, we have studied only 24 hypoprolific boars. Among them 10 were carrying a translocation, which represents about 0.6 p. 1000 .

In a recent paper, we estimated the financial consequences of a hypothetical chromosomal abnormality, using the simulation model PORSIM (PoPESCU \& TIXIER, 1984). So, in a herd of 42 sows, a translocation carrying boar was used for 9 months along with a normal boar. Comparison of the income of this farmer with a control farmer showed a 48 to 57 p. 100 reduction, depending on the type of production : i.e. 4000 to $6000 \$$.

The frequency of chromosome abnormalities in the pig and their deleterious consequences for pig production clearly indicate the practical aspect of cytogenetic evaluation of breeding animals, in particular those intended for artificial insemination.

Received October 28, 1985.

Accepted December 20, 1985.

\section{References}

ÅkesSON A., Henricson B., 1972. Embryonic death in pigs caused by unbalanced karyotype. Acta. Vet. Scand., 13, 151-160.

Bahri I., Bonneau M., Boscher J., Popescu C.P., 1984. Double heterozygote for reciprocal translocation in pigs. 6th Eur. Colloq. Cytogenet. Domest. Anim. July 16-20, 1984 , Zürich, 275-289, Institut for Animal Production E.T.H., Zürich.

Bouters R., Bonte P., Vandeplassche M., 1974. Anomalies chromosomiques et mortalité embryonnaire chez le porc. 1st World Congress on Genet. Applied to Livestock Production. 7-11 Oct., 1974, Madrid, 3, 169-171, Minist. Agric., Madrid.

FeichHeimer N.S., 1981. Cytogenetics in pig production. Pig news and information, 2, 387-391.

Ford C.E., Pollock D.L., Gustavsson I., 1980. Proceedings of the First International Conference for the standardisation of banded karyotypes of domestic animals, Reading. 1976. Hereditas, 92 (1), 145-162.

Förster M., Willeke H., Richter L., 1981. Eine autosomale, reziproke 1/16 Translokation bei Deutschen Landrasse Schwcinen. Zuchthyg., 16, 54-57.

Golisch D., Ritter E., Schwerin M., 1982. Zytogenetische Untersuchungen von Ebern unterschiedlicher genetischer Konstruktionen. Arch. Tierz., 25, 337-344.

Gustavsson I., SetTergren I., King A., 1982. Identification of three spontaneous reciprocal. translocations in the domestic pig. 5th Colloque Europ. Cytogenet. Anim. Domest. Milano-Gargnano, June 7-11, 1982, Milan. Sup. 24, 281-287. Ricerca Sientifica ed. educazione Permanente.

Hageltorn M., Gustavsson I., Zech L., 1973. The Q- and G-bandings patterns of a $\mathrm{t}$ $(11 \mathrm{p}+; 14 \mathrm{q}-)$ in the domestic pig. Hereditas, 75, 147-151.

Hageltorn M., Gustavsson I., Zech L., 1976. Detailed analysis in a reciprocal translocation $(13 \mathrm{q}-; 14 \mathrm{q}+)$ in the domestic pig by $\mathrm{G}$ - and Q-staining techniques. Hereditas, 83, 268-271. 
Henricson B., Backstrom L., 1964. Translocation heterozygosity in a boar. Hereditas, 52, 166-170.

King W.A., Gustavsson I., Popescu C.P., Linares T., 1981. Gametic products transmitted by rcp $(13 \mathrm{q}-; 14 \mathrm{q}+)$ translocation heterozygous pigs and resulting embryonic loss. Hereditas, 95, 239-246.

Legault C., Popescu C.P., 1981. Mise en évidence et conséquences zootechniques d'une translocation réciproque chez le porc. In $: 13^{\mathrm{e}}$ journées de la recherche porcine en France, 1981, 239-246. Institut Technique du Porc, Paris.

Locniskar F., Gustavsson I., Hageltorn M., Zech L., 1976. Cytological origin and points of exchange of a reciprocal chromosome translocation $(1 \mathrm{p}-; 6 \mathrm{q}+)$ in the domestic pig. Hereditas, 83, 272-275.

Madan K., Ford C.E., Polge G., 1978. A reciprocal translocation $t(6 p+; 14 q-)$ in the pig. J. Reprod. Fertil., 53, 395-398.

Popescu C.P., 1982 a. Cytogenetics in domestic animal production. 2nd World Cong. Genet. Appl. Livestock Prod., Madrid, 14th-18th Oct., 1982, Vol. 6, 375-384, Minist. Agric., Madrid.

Popescu C.P., 1982 b. Reciprocal translocation in pigs and consequences on their performances. Pig News and Information, 3, 255-257.

Popescu C.P., Legault C., 1979. Une nouvelle translocation, $\mathrm{t}(4 \mathrm{p}+; 14 \mathrm{q} \rightarrow$ ) chez le porc domestique (Sus scrofa domestica). Ann. Génét. Sél. Anim., 11, 361-369.

POPESCU C.P., Boscher J., 1982. Cytogenetics of pre-implantation embryos produced by pigs heterozygous for the reciprocal translocation $(4 \mathrm{q}+; 14 \mathrm{q}-)$. Cytogenet. Cell. Genet., 34, 119-123.

Popescu C.P., Boscher J., Tixier M., 1983. Une nouvelle translocation réciproque $t$, rcp $(7 \mathrm{q}-; 15 \mathrm{q}+)$ chez un verrat hypoprolifique. Génét. Sél. Evol., 15, 479-488.

Popescu C.P., Bonneau M., Tixier M., Bahri I., Boscher J., 1984. Reciprocal translocations in pigs. Their detection and consequences on animal performance and economic losses. J. Hered., 75, 448-452.

Popescu C.P., Tixier M., 1984. L'incidence des anomalies chromosomiques chez les animaux de ferme et leurs conséquences économiques. Ann. Génét., 27, 69-72. 